\title{
Diffuse large B-cell lymphoma associated with chronic inflammation as an incidental finding and new clinical scenarios
}

Florence Loong ${ }^{1}$, Alexander CL Chan ${ }^{2}$, Bernard CS Ho ${ }^{3}$, Yuk-Ping Chau ${ }^{3}$, Hwei-Yee Lee ${ }^{3}$, Wah Cheuk ${ }^{2}$, Wai-Key Yuen ${ }^{4}$, Wing-Shun $\mathrm{Ng}^{5}$, Hung-Leong Cheung ${ }^{5}$ and John KC Chan ${ }^{2}$

${ }^{1}$ Department of Pathology, Queen Mary Hospital, Hong Kong, China; ${ }^{2}$ Department of Pathology, Queen Elizabeth Hospital, Hong Kong, China; ${ }^{3}$ Department of Pathology, Tan Tock Seng Hospital, Singapore; ${ }^{4}$ Department of Surgery, Queen Mary Hospital, Hong Kong, China and ${ }^{5}$ Department of Cardiothoracic Surgery, Queen Elizabeth Hospital, Hong Kong, China

Diffuse large B-cell lymphoma that develops in the setting of long-standing chronic inflammation is typically associated with Epstein-Barr virus, and usually presents as tumor mass involving body cavities, as in pyothorax-associated lymphoma. It is listed as a distinct entity in the latest World Health Organization lymphoma classification. We report four cases that were incidentally discovered on histologic examination, one each in a splenic false cyst, a long-standing hydrocele, an atrial myxoma, and metallic-implant wear debris. Microscopic foci of atypical (neoplastic) large lymphoid cells were found within the contents of the cysts or curettage material, or within the stroma of the atrial myxoma. Despite the diverse clinical scenarios, all cases showed a homogeneous phenotype: positivity for B-lineage markers (CD20 +, CD79a +, PAX5 +), non-germinal center immunophenotype (CD10-, BCL6-I+, MUM-1+), and positivity for Epstein-Barr virus with type III latency (LMP1 +, EBNA2 + ). The last feature supports the hypothesis that the lymphoma has arisen in a setting of 'local immunodeficiency' as a result of long-standing chronic inflammation in an enclosed space, a characteristic pathogenetic mechanism of diffuse large B-cell lymphoma associated with chronic inflammation. These cases therefore expand the spectrum of this entity to include new clinical scenarios for the development of this lymphoma type.

Modern Pathology (2010) 23, 493-501; doi:10.1038/modpathol.2009.168; published online 8 January 2010

Keywords: B-cell lymphoma; chronic inflammation; Epstein-Barr virus

In 1987, Iuchi et $a l^{1}$ first reported three cases of pleural B-cell lymphoma in Japanese patients with chronic pyothorax resulting from artificial pneumothorax for treatment of pulmonary tuberculosis or tuberculous pleuritis. Non-autoimmune type of chronic inflammatory stimulus was suggested as an etiology. Subsequently, many more cases have been reported in Japanese patients, under the designation 'pyothorax-associated lymphoma' (PAL). ${ }^{2,3}$ This lymphoma type has also been uncommonly reported in Western patients. ${ }^{4-7}$ It shows features of diffuse large B-cell lymphoma (DLBCL)

Correspondence: Dr F Loong, MB, BS, Department of Pathology, Queen Mary Hospital, Pokfulam Road, Hong Kong SAR, China. E-mail: floong@pathology.hku.hk

Received 12 August 2009; revised and accepted 14 October 2009; published online 8 January 2010 exhibiting consistent association with Epstein-Barr virus (EBV) ${ }^{8,9}$ Lymphomas with similar features are also recognized to develop in other chronic inflammatory conditions, such as use of metallic implants in bones and joints, ${ }^{10}$ chronic osteomyelitis, ${ }^{11}$ chronic venous ulcer, ${ }^{11}$ and use of surgical mesh implant. ${ }^{12}$ In 2008, the World Health Organization classification of tumors of hematopoietic and lymphoid tissues has adopted 'DLBCL associated with chronic inflammation' as a distinct entity and unifying concept for this group of lymphomas. ${ }^{13}$ We report four cases discovered incidentally in long-standing pathologic lesions, which contrast with the presence of frank tumor masses in the typical cases of DLBCL associated with chronic inflammation. These cases also broaden the clinical scenarios for the development of this lymphoma type. 


\section{Materials and methods}

\section{Patients and Pathologic Materials}

The four cases were collected from Queen Mary Hospital and Queen Elizabeth Hospital of Hong Kong, as well as Tan Tock Seng Hospital of Singapore. All represented lymphomas were found incidentally on microscopic examination of excision specimens. Case 4 has been reported earlier, ${ }^{10}$ but clinical information was updated, and additional immunostains were performed.

The surgical specimens were fixed in buffered formalin and processed routinely. Paraffin sections were stained with hematoxylin-eosin (H\&E).

\section{Immunohistochemistry}

Immunohistochemical staining was performed on deparaffinized tissue sections using a labeled streptavidin-biotin peroxidase or polymer detection system on automated immunostainers (Ventana Medical System, Tucson, AZ, USA or BOND-MAX, Vision BioSystems, Australia), according to the protocols of the manufacturers. After heat-induced antigen retrieval, the tissue sections were immunostained with a panel of antibodies as listed in Table 1.

\section{Molecular Studies}

Paraffin sections were studied for the presence of EBV and immunoglobulin light chain restriction by in situ hybridization for EBV-encoded early small nuclear RNAs (EBER), kappa light chain mRNA, and lambda light chain mRNA. The tests were performed by BOND-MAX automated immunostainer. After digestion with enzyme, the slides were incubated with specific fluorescein-conjugated probes, followed by anti-fluorescein antibody, polymer conjugated with peroxidase and anti-rabbit/mouse IgG, and diaminobenzidine solution.

In cases 3 and 4, DNA was extracted from paraffinembedded material (selected for areas rich in atypical large lymphoid cells), and studied for immunoglobulin gene rearrangement by polymerase chain reaction (PCR), using primers against framework 2 and framework 3 , as described earlier. ${ }^{14}$

Table 1 Antibodies and probes used for immunohistochemical staining and in situ hybridization

\begin{tabular}{|c|c|c|c|}
\hline Antibody or probe & Source & Clone & Dilution \\
\hline \multicolumn{4}{|l|}{ Immunohistochemistry } \\
\hline \multicolumn{4}{|l|}{$B$-cell markers } \\
\hline CD20 & Dako & L26 & $1: 2400$ \\
\hline CD79a & Dako & JCB117 & $1: 75$ \\
\hline PAX5 & Biocare & $\mathrm{BC} / 24$ & $1: 30$ \\
\hline \multicolumn{4}{|l|}{ Germinal center and non-germinal center markers } \\
\hline CD10 & Novocastra & $56 \mathrm{C} 6$ & $1: 100$ \\
\hline BCL6 & Novocastra & LN22 & $1: 100$ \\
\hline MUM-1 & Dako & MUM1p & $1: 200$ \\
\hline CD138 & Dako & MI15 & $1: 150$ \\
\hline BCL2 & Dako & 124 & $1: 30$ \\
\hline \multicolumn{4}{|l|}{ T-cell markers } \\
\hline CD2 & Novocastra & AB75 & $1: 50$ \\
\hline CD3 & Novocastra & PS1 & $1: 150$ \\
\hline CD5 & Novocastra & $4 \mathrm{C} 7$ & $1: 100$ \\
\hline CD7 & Novocastra & CD7-272 & $1: 75$ \\
\hline $\mathrm{CD} 43$ & Biotest & MT1 & $1: 600$ \\
\hline \multicolumn{4}{|l|}{ Proliferation and activation markers } \\
\hline Ki67 & Dako & MIB1 & $1: 250$ \\
\hline CD30 & Dako & Ber-H2 & $1: 30$ \\
\hline \multicolumn{4}{|l|}{ Viral markers } \\
\hline EBV-LMP1 (EBV latent membrane protein 1) & Dako & Cocktail of CS1-4 & $1: 800$ \\
\hline EBNA-2 (EBV nuclear antigen 2) & Novocastra & PE2 & $1: 50$ \\
\hline Human herpes virus 8 & Novocastra & $12 \mathrm{~B} 10$ & $1: 50$ \\
\hline \multicolumn{4}{|l|}{ In situ hybridization } \\
\hline EBER & Novocastra & Epstein-Barr virus probe (fluorescein conjugated) & NA \\
\hline Kappa light chain mRNA & Novocastra & Kappa Probe (fluorescein conjugated) & NA \\
\hline Lambda light chain mRNA & Novocastra & Lambda Probe (fluorescein conjugated) & NA \\
\hline
\end{tabular}

Dako, Dako Corporation (Carpinteria, CA, USA).

Biocare, Biocare Medical (Concord, CA, USA).

Novocastra, Novocastra (Newcastle Upon Tyne, England, UK).

Biotest, Clonab, Biotest Diagnostics (Dreieich, Germany). 


\section{Results}

\section{Clinical Findings}

The clinical features are summarized in Table 2. All patients were Chinese, with ages ranging from 29 to 88 years. None had a known history of lymphoma. They all underwent excision of their presenting conditions. One patient (case 2) was lost to followup after operation. The other three patients did not show evidence of lymphoma on postoperative staging work up. They received postoperative antiCD20 (rituximab) with or without chemotherapy, or local radiation. One patient died from opportunistic infection after chemotherapy at 5 months; two were alive with no evidence of disease at 6 months and 7 years, respectively.

\section{Pathologic Findings}

\section{Case-specific features}

In case 1, the enlarged spleen weighed $900 \mathrm{~g}$, with most of the parenchyma replaced by an 18-cm cyst. The cyst had a fibrous wall measuring $0.5 \mathrm{~cm}$ thick, with old blood and brownish material adherent to the luminal side (Figure 1a). Histologically, the cyst wall consisted of hyalinized fibrous tissue with dystrophic calcification and patchy chronic inflammatory cell infiltration (Figure 1b). The cyst was devoid of epithelial lining, and it contained hemor- rhagic and necrotic material, hemosiderin pigment, and cholesterol crystals, in keeping with previous hemorrhage. The morphology was compatible with splenic false cyst. In 8 of the 23 sampled blocks, small aggregates of atypical large lymphoid cells were seen within inner fibrous zone or necrotic material, with each aggregate measuring no more than $1.5 \mathrm{~mm}$ (Figure 1c). The compressed rim of splenic parenchyma showed unremarkable red and white pulp.

In case 2, the testis was atrophic, and the paratesticular abscess tissue measured $10.5 \times 8 \times 5.5 \mathrm{~cm}$. Histologically, the paratesticular tissue showed dense fibrous pseudocapsule with central necrotic debris, proteinaceous material, cholesterol crystals, and mixed acute and chronic inflammatory infiltrate (Figure 2a). In 1 of the 20 sampled blocks, clusters of atypical large lymphoid cells were found within the central necrotic debris (Figure 2b).

In case 3 , the polypoid left atrial tumor measured $6.5 \mathrm{~cm}$ in diameter. Microscopy showed a typical cardiac myxoma, characterized by single or cords of spindly or stellate tumor cells suspended in a myxoid stroma, and immunoreactivity for calretinin (Figures 3a and b). Multiple tiny aggregates of large lymphoid cells (largest focus $1 \mathrm{~mm}$ in diameter) were scattered within the stroma of the cardiac myxoma, in 10 of the 14 sampled blocks (Figure 3c).

In case 4, the wear debris showed mainly necrotic material, and hyalinized fibrous tissue with abundant

Table 2 Clinical information

\begin{tabular}{|c|c|c|c|}
\hline Case & Sex/age & Presentation and clinical findings & Outcome \\
\hline 1 & $\mathrm{M} / 29$ & $\begin{array}{l}\text { Left upper quadrant pain for } 1 \text { month. CT scan showed a } \\
\text { large splenic cyst with possible recent hemorrhage. } \\
\text { Laparoscopy found an 18-cm splenic cyst containing } 21 \\
\text { of brownish fluid. Splenectomy was performed }\end{array}$ & $\begin{array}{l}\text { Bone marrow examination and whole body positron } \\
\text { emission tomography did not show lymphoma } \\
\text { elsewhere. The patient received four courses of } \\
\text { rituximab (anti-CD20) } 4 \text { months postoperation. Well } \\
\text { with no evidence of disease at } 6 \text { months }\end{array}$ \\
\hline 2 & $\mathrm{M} / 88$ & $\begin{array}{l}\text { Known history of diabetes mellitus, ischemic heart } \\
\text { disease, hypertension, prostatic nodular hyperplasia, } \\
\text { and chronic untreated right hydrocele ( } 18 \text { years). } \\
\text { Presented with fever and right scrotal pain and swelling } \\
\text { for } 2 \text { weeks. Ultrasound showed a large right hydrocele. } \\
\text { Right orchidectomy was performed after antibiotic } \\
\text { therapy. Operative findings showed paratesticular } \\
\text { abscess and necrosis of right testis }\end{array}$ & Well postoperatively. Lost to follow-up postoperation \\
\hline 3 & $\mathrm{~F} / 70$ & $\begin{array}{l}\text { Known history of hypertension and diabetes mellitus. } \\
\text { Presented with cardiogenic shock, bradycardia, acute } \\
\text { renal failure, and ischemic stroke. Echocardiogram } \\
\text { revealed a large left atrial mass }(6.5 \times 4.0 \mathrm{~cm}) \text { with } \\
\text { mitral valve inflow obstruction. The tumor was } \\
\text { completely resected by open heart surgery }\end{array}$ & $\begin{array}{l}\text { Gradual recovery with persistent right hemiplegia } \\
\text { postoperatively. Subsequent CT staging revealed no } \\
\text { other tumor. Marrow examination was negative. Four } \\
\text { cycles of chemotherapy (R-CEOP: rituximab, } \\
\text { cyclophosphamide, epirubicin, vincristine, and } \\
\text { prednisone) were given. Repeat CT scan was negative. } \\
\text { Died from complications of chemotherapy (neutropenic } \\
\text { fever and opportunistic pneumonia) at } 5 \text { months }\end{array}$ \\
\hline $4^{\mathrm{a}}$ & $\mathrm{M} / 78$ & $\begin{array}{l}\text { Had total knee replacement } 32 \text { years ago for fixed } \\
\text { flexion deformity of right knee due to septic arthritis. } \\
\text { Replacement of prosthesis } 16 \text { years ago. Presented } \\
\text { with increasing right knee pain. A new prosthesis was } \\
\text { implanted, and large amount of wear debris was } \\
\text { found around the loosened femoral stem of prosthesis }\end{array}$ & $\begin{array}{l}\text { Staging work-up revealed no other sites of disease. } \\
\text { Postoperative involved field radiotherapy ( } 28 \mathrm{~Gy} \text { in } 7 \\
\text { fractions) was given. Alive and well at } 7 \text { years }\end{array}$ \\
\hline
\end{tabular}

CT: computerized tomography; FDG: fluorodeoxyglucose.

${ }^{\mathrm{a}}$ Previously reported by Cheuk et $a l,{ }^{10}$ with update of follow-up. 


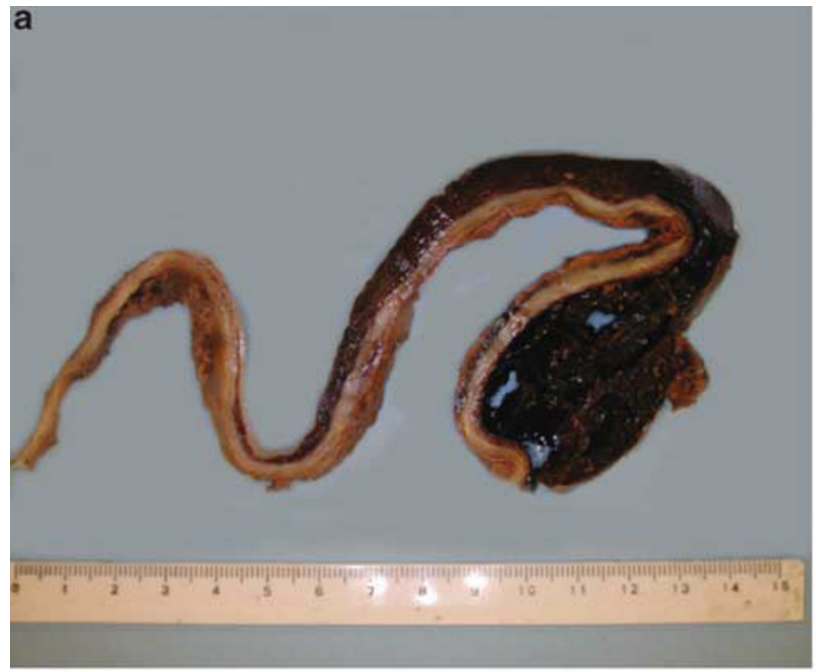

b
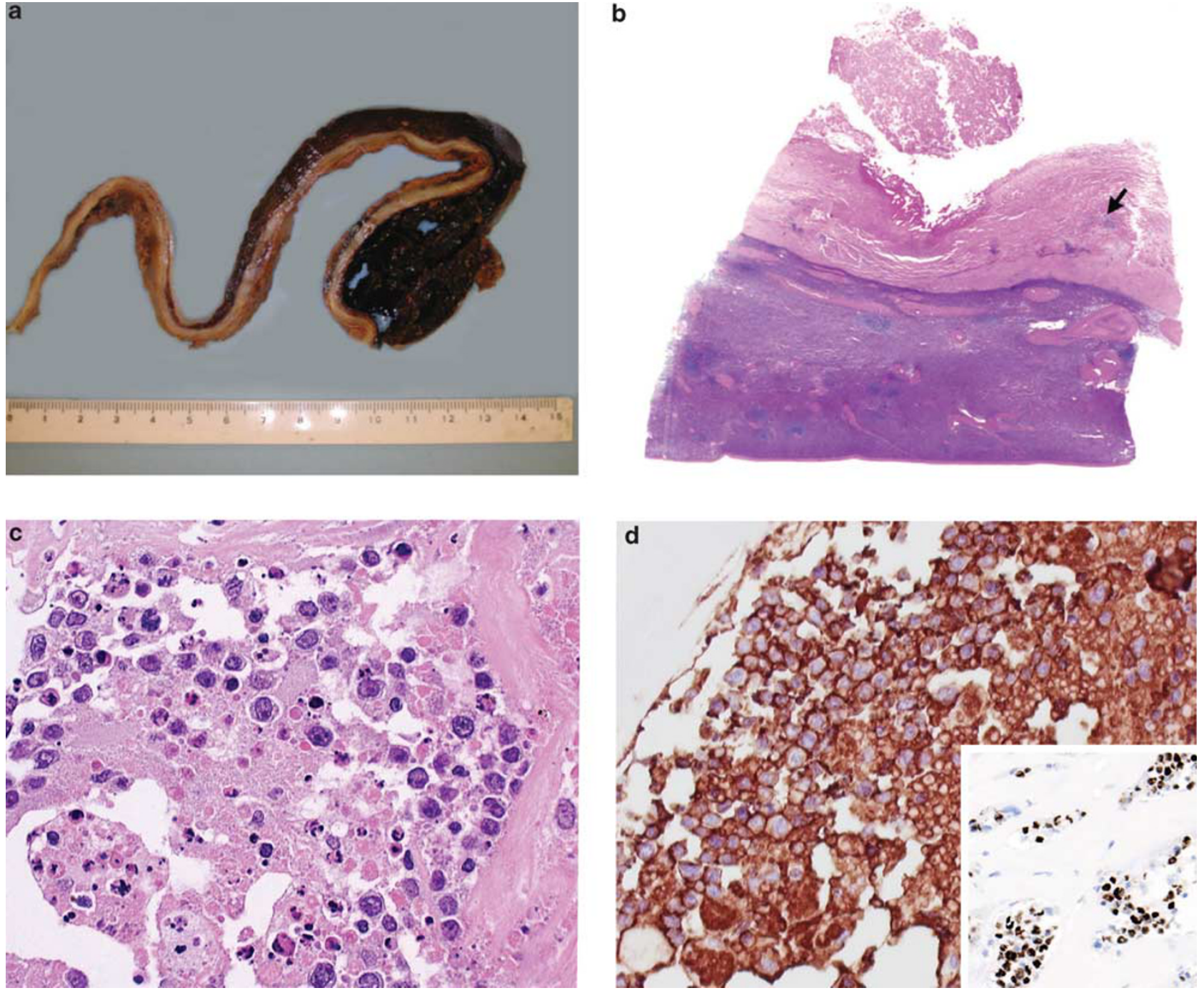

Figure 1 Case 1. (a) The splenic cyst is lined by fibrotic wall with adherent brownish material. A rim of normal splenic parenchyma is noted at the periphery. (b) Scanning magnification of cyst. From top to bottom: luminal necrotic material, inner fibrous zone with a microscopic focus of atypical lymphoid cells (arrow), sclerotic cyst wall, and splenic tissue. (c) The atypical lymphoid cells have large, round nuclei with coarse chromatin and small nucleoli. There are admixed apoptotic bodies. (d) The large lymphoid cells are CD20 positive. They are remarkably highlighted by immunostaining for EBNA-2 (inset).

pigment-laden or granular histiocytes. Several small clusters of atypical large lymphoid cells were identified in 2 of the 8 sampled blocks.

\section{Morphology of lymphoma cells}

The atypical large lymphoid cells found in the four cases occurred singly or in small aggregates. They had irregularly folded or oval nuclei, distinct nucleoli, and a moderate amount of amphophilic cytoplasm (Figures 1c, 2b, and 3d). Some had segmented or binucleated nuclei (Figure 3d). Some cells appeared degenerated or necrotic (Figure 2b).

\section{Immunohistochemistry}

The immunohistochemical results are summarized in Table 3 . The large lymphoid cells were B-cells expressing CD20, CD79a, and PAX5 (Figures 1d, 2c, and 3e). All cases showed a non-germinal center immunophenotype (CD10-, BCL6-/ +, MUM-1 + ). The cells were highly proliferative, with Ki67 index ranging from 70 to $100 \%$. All cases were positive for EBV LMP-1 and EBNA-2 (Figure 1d).

Cases 1, 3, and 4 showed aberrant expression of CD43. Case 2 also expressed CD3 (Figure 2d), but other T-cell markers including CD2, CD5, and CD7 were all negative.

\section{Molecular Studies}

The lymphoma cells were diffusely positive for EBER on in situ hybridization (Figure 3f). Kappa light chain mRNA restriction was shown in cases 1 and 3 . The lymphoma cells did not show labeling for 

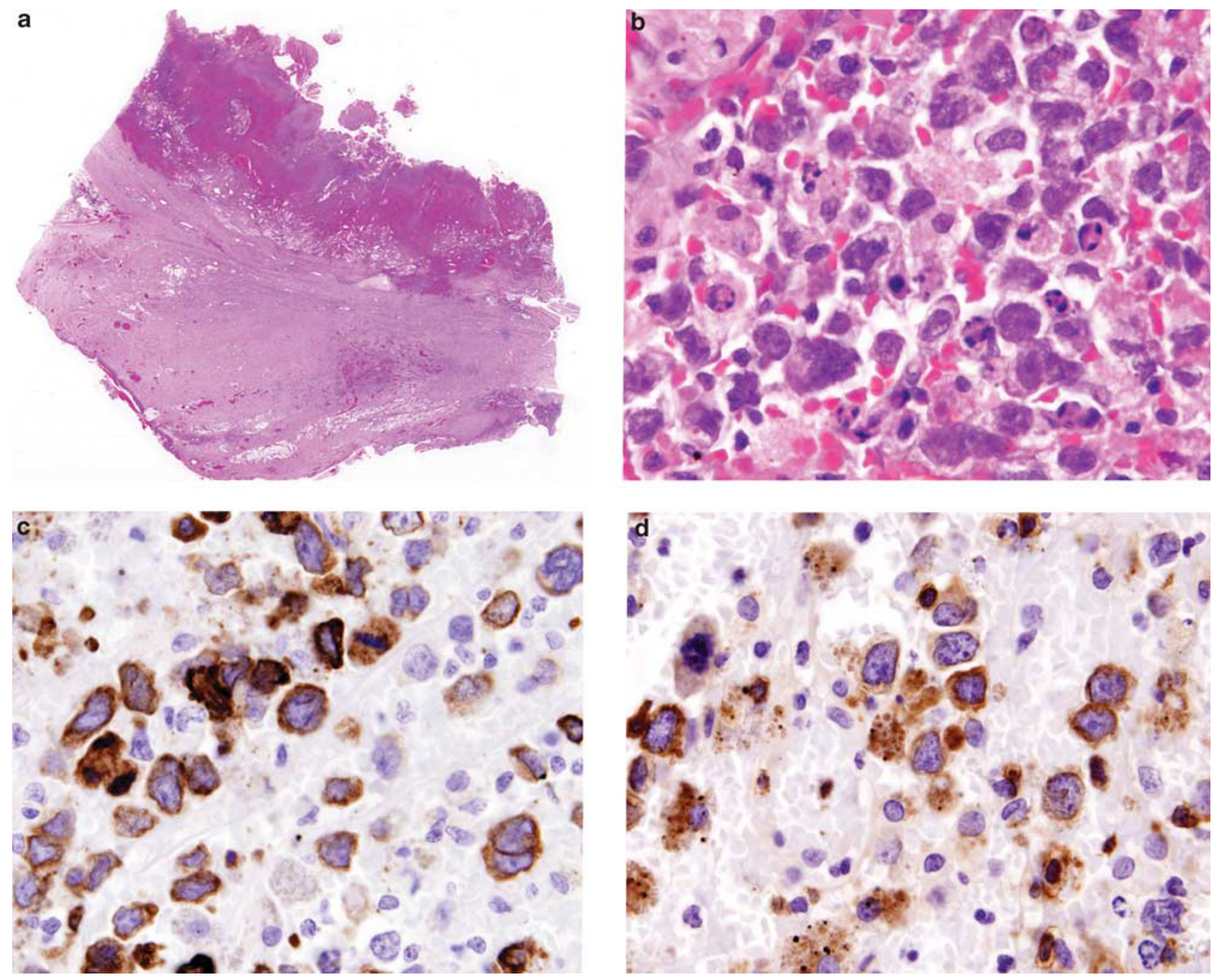

Figure 2 Case 2. (a) The paratesticular mass shows thick fibrous pseudocapsule with mixed inflammatory cell infiltration. Blood and necrotic material are adherent on the luminal side (upper field). (b) The atypical lymphoid cells show large irregularly folded nuclei and distinct nucleoli and are admixed with cell debris. (c) The lymphoma cells are immunoreactive for CD79a. (d) Many of them also stain for CD3 in the cytoplasm with perinuclear accentuation.

kappa or lambda mRNA in cases 2 and 4 . In both cases 3 and 4, clonal immunoglobulin gene rearrangements were shown by PCR.

\section{Discussion}

This report describes four unusual cases of lymphoma incidentally found in various chronic pathologic lesions. The interpretation of the microscopic aggregates of large lymphoid cells as lymphoma cells is based on the presence of definite cytologic atypia, aberrant immunophenotype (CD43 coexpression in all three tested cases), immunoglobulin light chain restriction ( 2 of 4 cases), very high proliferative index, uniform labeling of the large lymphoid cells for EBV, and immunoglobulin gene rearrangement ( 2 of 2 cases). All cases were primary localized lymphomas, as subsequent investigations did not show involvement of other organs. Despite the diverse clinical scenarios, they conform to DLBCL associated with chronic inflammation, ${ }^{13}$ as supported by the following findings: (1) occurrence in an enclosed environment, (2) clinical or histologic evidence of long-standing or slow-growing lesion with chronic inflammation, (3) morphologic features of DLBCL, (4) B-cell immunophenotype, and (5) association with EBV. Besides the incidental discovery, these cases differ from the usual lymphomas reported in the respective organs.

Although the spleen is commonly involved by lymphoma, ${ }^{15}$ cystic presentation is unusual except secondary to tumor necrosis, infection, or hemorrhage. ${ }^{16}$ In contradistinction to splenic DLBCL with infarction followed by cystic degeneration, case 1 shows features typical of splenic false cyst (young patient age and a zoned architecture), ${ }^{17}$ the viable lymphoma cells are found in the inner 

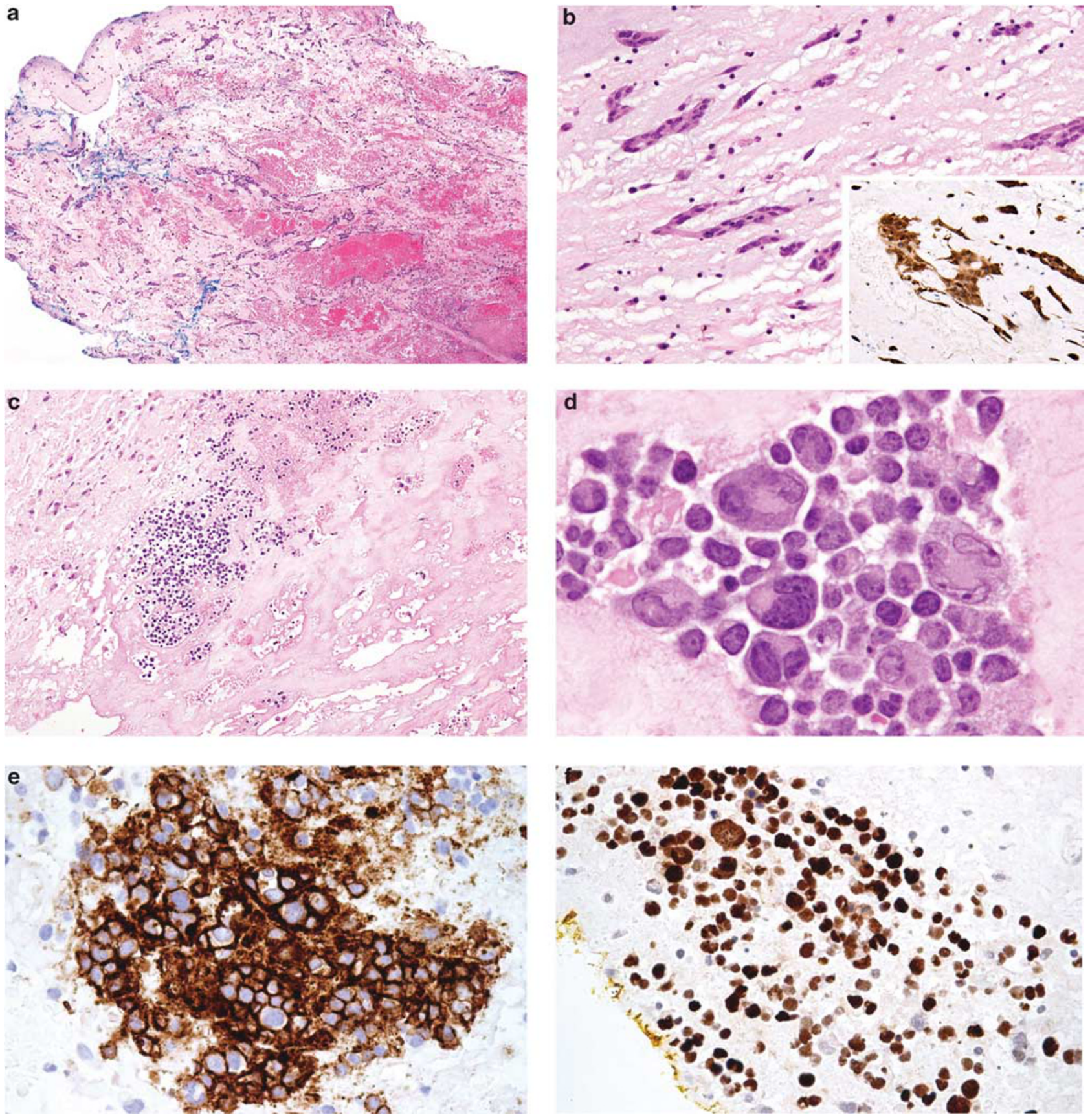

Figure 3 Case 3. (a) The polypoid left atrial tumor had a myxoid stroma with hemorrhagic foci. (b) Single and cords of cells are disposed in a myxoid to myxohyaline matrix, compatible with atrial myxoma. The tumor cells are immunoreactive for calretinin (inset). (c) Microscopic foci of atypical lymphoid cells are found within the myxohyaline stroma of the atrial myxoma. (d) The atypical lymphoid cells are large and vary in size. They show irregularly folded or segmented nuclei, and distinct nucleoli. The cytoplasm is amphophilic. (e) These cells are highlighted by the B-cell marker CD20. (f) In situ hybridization for EBER is positive.

fibrous zone rather than the peripheral zone of the cyst wall, and EBV is positive with type III latency (see discussion below).

Likewise, case 2, with a long history of hydrocele, differs from the uncommon primary paratesticular lymphomas, which typically present with solid tumor or enlarged epididymis. ${ }^{18-22}$ In the rare reported cases of testicular plasmacytoma associated with hydrocele, the neoplasm formed a tumorous mass and the hydrocele occurred as a complication instead of being a preexisting condition. ${ }^{23}$

Primary cardiac lymphomas are extremely rare in immunocompetent patients. ${ }^{24}$ Exceptional cases can mimic cardiac myxoma clinically. ${ }^{25,26}$ In case 3 , the cardiac myxoma may have provided the 'soil' for the chronic inflammation, as cardiac myxoma can 
Table 3 Results of immunohistochemical staining and in situ hybridization

\begin{tabular}{|c|c|c|c|c|}
\hline Antibody or probe & Case 1 & Case 2 & Case 3 & Case 4 \\
\hline \multicolumn{5}{|l|}{ Immunohistochemistry } \\
\hline \multicolumn{5}{|l|}{$B$-cell markers } \\
\hline CD20 & +++ & +++ & +++ & +++ \\
\hline CD79a & +++ & +++ & +++ & +++ \\
\hline PAX5 & +++ & +++ & +++ & +++ \\
\hline \multicolumn{5}{|c|}{ Germinal center and non-germinal center markers } \\
\hline CD10 & - & - & - & - \\
\hline BCL6 & - & - & ++ & - \\
\hline MUM-1 & +++ & + & +++ & ++ \\
\hline CD138 & - & - & - & + \\
\hline BCL2 & +++ & +++ & +++ & +++ \\
\hline \multicolumn{5}{|l|}{ T-cell markers } \\
\hline $\mathrm{CD} 2$ & - & - & - & - \\
\hline CD3 & - & +++ & - & - \\
\hline CD5 & - & - & - & - \\
\hline CD7 & - & - & - & - \\
\hline $\mathrm{CD} 43$ & +++ & ND & ++ & +++ \\
\hline \multicolumn{5}{|c|}{ Proliferation and activation markers } \\
\hline Ki67 & $90 \%$ & $70 \%$ & $100 \%$ & $70 \%$ \\
\hline CD30 & - & - & ++ & +++ \\
\hline \multicolumn{5}{|l|}{ Viral markers } \\
\hline EBV-LMP1 & + & + & +++ & +++ \\
\hline EBNA-2 & +++ & +++ & +++ & +++ \\
\hline Human herpes virus 8 & - & - & - & - \\
\hline \multicolumn{5}{|l|}{ In situ hybridization } \\
\hline EBER & +++ & +++ & +++ & +++ \\
\hline Kappa light chain mRNA & +++ & - & ++ & - \\
\hline Lambda light chain mRNA & - & - & - & - \\
\hline
\end{tabular}

NA: not applicable; ND: not done; -: all tumor cells were negative, $-/+$ : rare tumor cells were positive, $+: 5-25 \%$ of tumor cells were positive, $++: 26-50 \%$ of tumor cells were positive, $+++:>50 \%$ of tumor cells were positive.

produce proinflammatory cytokines and be associated with systemic inflammatory symptoms. ${ }^{27}$ Recently, Bagwan et $a 1^{28}$ reported two cases of incidental DLBCL, one in a valvular homograft and one in an atrial myxoma, quite similar to case 3 . However, both cases showed a germinal center cell immunophenotype instead, and one tested case was negative for EBV-LMP1. As results on EBER and EBNA-2 are not available, it is unclear whether these two cases represent DLBCL associated with chronic inflammation.

Primary bone lymphomas are mostly DLBCLs, which arise de novo and lack association with EBV. However, the cases associated with osteomyelitis or metallic implant show distinctive features as in case 4 , such as long latency between onset of inflammatory process and development of lymphoma, and association with EBV. ${ }^{10}$

All four cases in this series show a consistent nongerminal center cell immunophenotype, similar to the findings in $\mathrm{PAL},{ }^{7}$ the prototype of DLBCL associated with chronic inflammation. Also similar to PAL, ${ }^{3,7-9,29}$ all four cases express both LMP-1 and
EBNA-2, indicating a type III EBV latency. EBVassociated lymphomas may exhibit type I latency (LMP-1 and EBNA-2 negative), such as Burkitt lymphoma; type II latency (LMP-1 positive, EBNA2 negative), such as Hodgkin lymphoma, peripheral T-cell lymphoma, and extranodal NK/T cell lymphoma; and type III latency (LMP-1, EBNA-2, EBNA-3 positive), such as posttransplant lymphoproliferative disorder, PAL, and some cases of $\mathrm{EBV}+$ DLBCL of the elderly (postulated to be related to senescence-associated decline in immunocompetence). ${ }^{30,31}$ That is, type III EBV latency is the hallmark of EBV-associated lymphomas arising in the setting of immunodeficiency. As EBNA-2 and EBNA-3 are highly immunogenic, lymphoma cells bearing these proteins would have been eliminated by EBV-specific cytotoxic T lymphocytes if the latter had not been drastically reduced as a result of immunodeficiency. ${ }^{32}$ In DLBCL associated with chronic inflammation, it has been postulated that local rather than systemic immunosuppression has an important function in its pathogenesis. Cytokines derived from the chronic inflammatory cells, EBV-immortalized B-cells or lymphoma cells can build up to high levels in the enclosed space. For example, interleukin-10, which inhibits T-cell proliferation through inhibition of monocytemacrophage antigen presenting cells and cytokine production, ${ }^{32,33}$ may contribute to the local immunosuppressive effects. ${ }^{34,35}$ The dense fibrosis of the cyst walls, intra-cardiac myxoma localization, or intra-articular location may also provide an enclosed environment permitting the EBV-infected memory B-cells to evade T-cell immunosurveillance. Coupled with the stimulatory effects of other cytokines such as interleukin-6, EBV-infected cells can accumulate genetic alterations for clonal selection with subsequent evolution to lymphoma. ${ }^{34,36-38}$

One of the four cases (case 2) shows aberrant expression of the T-cell antigen CD3. Of interest, among the small numbers of cases of CD3-positive B-cell lymphomas reported in the literature, ${ }^{7,39,40}$ PAL accounts for a significant fraction. The 'local immunodeficiency' may promote this dual immunophenotype, akin to the increased frequency of biphenotypic or bigenotypic lymphomas that occur in the setting of immunodeficiency, and which are often associated with EBV. ${ }^{39,41}$

It is likely that DLBCL associated with chronic inflammation will also be incidentally found in other comparable settings, such as in long-standing thyroid cyst, ovarian cyst, or pancreatic pseudocyst. The optimal treatment for these incidental DLBCLs in contrast to the generally aggressive DLBCLs associated with chronic inflammation that present with frank tumors remains unclear. Although the current standard treatment for localized extranodal DLBCL (stage IE-IIE) is R-CHOP (rituximab, cyclophosphamide, adriamycin, vincristine, and prednisone) chemotherapy, usually followed by involved 
field radiation, ${ }^{42}$ this may represent over-treatment for such miniscule tumor volume, especially as the lymphoma might have been totally removed with the diseased organ or pathological lesion.

\section{Disclosure/conflict of interest}

Case 3 has been presented as an abstract at the 17th Annual Meeting of the Asian Society for the Cardiovascular and Thoracic Surgery (ASCVTS 2009), Taipei, Taiwan, 5-8 March 2009.

\section{References}

1 Iuchi K, Ichimiya A, Akashi A, et al. Non-Hodgkin's lymphoma of the pleural cavity developing from longstanding pyothorax. Cancer 1987;60:1771-1775.

2 Iuchi K, Aozasa K, Yamamoto S, et al. Non-Hodgkin's lymphoma of the pleural cavity developing from longstanding pyothorax. Summary of clinical and pathological findings in thirty-seven cases. JPN J Clin Oncol 1989;19:249-257.

3 Nakatsuka S, Yao M, Hoshida Y, et al. Pyothoraxassociated lymphoma: a review of 106 cases. J Clin Oncol 2002;20:4255-4260.

4 Martin A, Capron F, Liguory-Brunaud M-D, et al. Epstein-Barr virus-associated primary malignant lymphomas of the pleural cavity occurring in longstanding pleural chronic inflammation. Hum Pathol 1994;25:1314-1318.

5 Moliniē V, Pouchot J, Navratil E, et al. Primary EpsteinBarr virus-related non-Hodgkin's lymphoma of the pleural cavity following long-standing tuberculous empyema. Arch Pathol Lab Med 1996;120:288-291.

6 Ascani S, Piccioli M, Poggi S, et al. Pyothoraxassociated lymphoma: description of the first two cases detected in Italy. Ann Oncol 1997;8:1133-1138.

7 Petitjean B, Jardin F, Joly B, et al. Pyothorax-associated lymphoma. A peculiar clinicopathologic entity derived from B cells at late stage of differentiation and with occasional aberrant dual B- and T-cell phenotype. Am J Surg Pathol 2002;26:724-732.

8 Fukayama M, Ibuka T, Hayashi Y, et al. Epstein-Barr virus in pyothorax-associated pleural lymphoma. Am J Pathol 1993;143:1044-1049.

9 Sasajima Y, Yamabe H, Kobashi Y, et al. High expression of the Epstein-Barr virus latent protein EB nuclear antigen-2 on pyothorax-associated lymphoma. Am J Pathol 1993;143:1280-1285.

10 Cheuk W, Chan ACL, Chan JKC, et al. Metallic implant-associated lymphoma. A distinct subgroup of large B-cell lymphoma related to pyothorax-associated lymphoma? Am J Surg Pathol 2005;29:832-836.

11 Copie-Bergman C, Niedobitek G, Mangham DC, et al. Epstein-Barr virus in B-cell lymphomas associated with chronic suppurative inflammation. J Pathol 1997;183:287-292.

12 Fujimoto M, Haga H, Okamoto M, et al. EBV-associated diffuse large B-cell lymphoma arising in the chest wall with surgical mesh implant. Pathol Int 2008;58: 668-671.

13 Chan JKC, Aozasa K, Gaulard P. DLBCL associated with chronic inflammation. In: Swerdlow SH, Campo E, Harris NL et al. (eds). WHO Classification of
Tumours of Haematopoietic and Lymphoid Tissues. IARC Press: Lyon, 2008, pp 245-246.

14 Diss TC, Pan L, Peng H, et al. Sources of DNA for detecting B cell monoclonality using PCR. J Clin Pathol 1994;47:493-496.

15 Sandrasegaran K, Robinson PJ, Selby P. Staging of lymphoma in adults. Clin Radiol 1994;49:149-161.

16 Urrutia M, Mergo PJ, Ros LH, et al. Cystic masses of the spleen: radiologic-pathologic correlation. Radiographics 1996;16:107-129.

17 Garvin DF, King FM. Cysts and nonlymphomatous tumors of the spleen. Pathol Annu 1981;16(Pt 1):61-80.

18 Heaton JP, Morales A. Epididymal lymphoma: an unusual scrotal mass. J Urol 1984;131:353-354.

19 Ginaldi L, De Pasquale A, De Martinis M, et al. Epididymal lymphoma. A case report. Tumori 1993;79:147-149.

20 McDermott MB, O’Brian DS, Shiels OM, et al. Malignant lymphoma of the epididymis. A case report of bilateral involvement by a follicular large cell lymphoma. Cancer 1995;75:2174-2179.

21 Vega F, Medeiros J, Abruzzo LY. Primary paratesticular lymphoma. A report of 2 cases and review of the literature. Arch Pathol Lab Med 2001;125:428-432.

22 Ferry JA, Harris NL, Young RH, et al. Malignant lymphoma of the testis, epididymis, and spermatic cord, a clinicopathologic study of 69 cases with immunophenotypic analysis. Am J Surg Pathol 1994;18:376-390.

23 Suzuki K, Shioji Y, Morita T, et al. Primary testicular plasmacytoma with hydrocele of the testis. Int J Urol 2001;8:139-140.

24 Chapter 13. Hematologic tumours of the heart and pericardium In: Burke A, Virmani R (eds). Atlas of Tumor Pathology. Tumors of the Heart and Great Vessels. 3rd edn. Armed Forces Institute of Pathology: Washington, DC, 1996, pp 171-179.

25 Quigley MM, Schwartzman E, Boswell PD, et al. A unique atrial primary cardiac lymphoma mimicking myxoma presenting with embolic stroke: a case report. Blood 2003;101:4708-4710.

26 Nguyen DT, Meier CR, Schneider D. Primary cardiac lymphoma mimicking left atrial myxoma in an immunocompetent patient. J Clin Oncol 2008;26: 150-152.

27 Wiedermann CJ, Reinisch N, Fischer-Colbrie R, et al. Proinflammatory cytokines in cardiac myxoma. J Intern Med 1992;232:263-265.

28 Bagwan IN, Desai S, Wotherspoon A, et al. Unusual presentation of primary cardiac lymphoma. Interact Cardiovasc Thorac Surg 2009;9:127-129.

29 Narimatsu H, Ota Y, Kami M, et al. Clinicopathological features of pyothorax-associated lymphoma; a retrospective survey involving 98 patients. Ann Oncol 2007;18:122-128.

30 Delecluse H-J, Kremmer E, Rouault J-P, et al. The expression of Epstein-Barr virus latent proteins is related to the pathological features of post-transplant lymphoproliferative disorders. Am J Pathol 1995; 146:1113-1120.

31 Rezk SA, Weiss LM. Epstein-Barr virus-associated lymphoproliferative disorders. Hum Pathol 2007;38: 1293-1304.

32 de Campos-Lima PO, Levitskaya J, Frisan T, et al. Strategies of immunoescape in Epstein-Barr virus persistence and pathogenesis. Semin Virol 1996;7: 75-82. 
33 Moore KW, O'Garra A, de Waal Malefyt R, et al. Interleukin-10. Annu Rev Immunol 1993;11:165-190.

34 Kanno H, Aozasa K. Mechanism for the development of pyothorax-associated lymphoma. Pathol Int 1998; 48:653-664.

35 Kanno H, Naka N, Yasunaga Y, et al. Production of the immunosuppressive cytokine interleukin-10 by EpsteinBarr-virus-expressing pyothorax-associated lymphoma. Possible role in the development of overt lymphoma in immunocompetent hosts. Am J Pathol 1997;150:349-357.

36 Akira S, Taga T, Kishimoto T. Interleukin-6 in biology and medicine. Adv Immunol 1993;54:1-78.

37 Tosato G, Tanner J, Jones KD, et al. Identification of interleukin-6 as an autocrine growth factor for EpsteinBarr virus-immortalized B cells. J Virol 1990;64: 3033-3041.

38 Danbara M, Takano Y, Fujino Y, et al. Development of pyothorax-associated pleural lymphoma in relation to focal cytokinemic condition and Epstein-Barr virus infection. Acta Haematol 1998;99:41-44.

39 Beaty M, Kumar S, Sorbara L, et al. A biphenotypic human herpesvirus 8-associated primary bowel lymphoma. Am J Surg Pathol 1999;23:992-994.

40 Wang J, Chen C, Lau S, et al. CD3-positive large B cell lymphoma. Am J Surg Pathol 2009;33:505-512.

41 Hollingsworth HC, Stetler-Stevenson M, Gagneten D, et al. Immunodeficiency-associated malignant lymphoma: three cases showing genotypic evidence of both T- and B-cell lineages. Am J Surg Pathol 1994; 18:1092-1101.

42 Gospodarowicz MG, Tsang RW, Connors JM. Specific management problems posed by the primary extranodal presentations: Part II - local control of localized disease. In: Cavilli F, Stein H, Zucca E (eds). Extranodal Lymphomas, Pathology and Management. Informa Healthcare: London, 2008, pp 58-63. 